
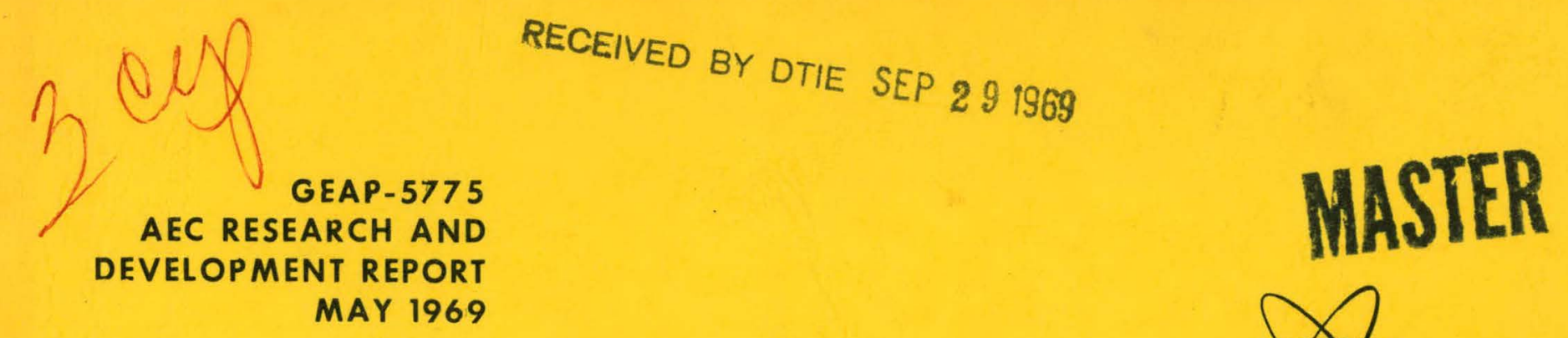

\title{
IMPACT TESTS AND FRACTURE TOUGHNESS
}

M. B. REYNOLDS

U. S. ATOMIC ENERGY COMMISSION CONTRACT AT(04-3)-189 PROJECT AGREEMENT 37

NUCLEONICS LABORATORY

VALLECITOS NUCLEAR CENTER

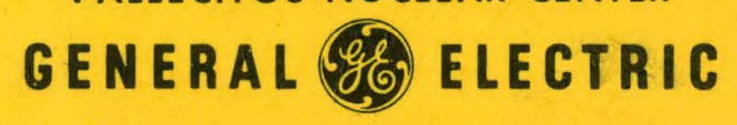

PLEASANTON, CALIFORNIA 


\section{DISCLAIMER}

This report was prepared as an account of work sponsored by an agency of the United States Government. Neither the United States Government nor any agency Thereof, nor any of their employees, makes any warranty, express or implied, or assumes any legal liability or responsibility for the accuracy, completeness, or usefulness of any information, apparatus, product, or process disclosed, or represents that its use would not infringe privately owned rights. Reference herein to any specific commercial product, process, or service by trade name, trademark, manufacturer, or otherwise does not necessarily constitute or imply its endorsement, recommendation, or favoring by the United States Government or any agency thereof. The views and opinions of authors expressed herein do not necessarily state or reflect those of the United States Government or any agency thereof. 


\section{DISCLAIMER}

Portions of this document may be illegible in electronic image products. Images are produced from the best available original document. 
GEAP- 5775

AEC Research and

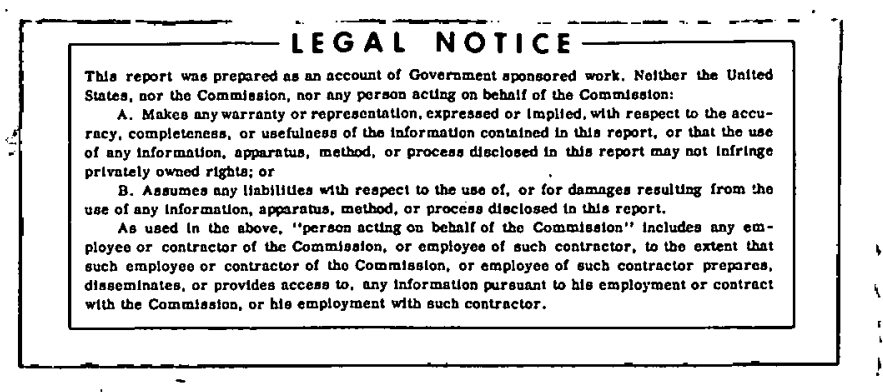

Development Report

May 1969

IMPACT TESTS AND FRACTURE TOUGHNESS

M. B. Reynolds

Approved:

$\frac{E 16 \text { Amhoff }}{\text { D. H. Imhoff, Manager }}$

Engineering Development

$\frac{S R \text { Verudenlury }}{S . R . ~ V a n d e n b e r g}$

S. R. Vandenberg

Project Engineer

United States Atomic Energy Commission

Contract No. AT(04-3)-189

Project Agreement 37

Printed in U.S. A. Available from the

Clearing House for Federal Scientific and Technical Information National Bureau of Standards, U. S. Department of Commerce Springfield, Virginia

Price: $\$ 3.00$ per copy

\section{NUCLEONICS LABORATORY \\ VALLECITOS NUCLEAR CENTER \\ GENERAL (960) ELETRIC \\ PLEASANTON, CALIFORNIA}




\section{LEGAL NOTICE}

This report was prepared as an account of Government sponsored work. Neither the United States, nor the Commission, nor any person acting on behalf of the Commission:

A. Makes any warranty or representation, expressed or implied, with respect to the accuracy, completeness, or usefulness of the information contained in this report, or that the use of any information, apparatus, methods, or process disclosed in this report may not infringe privately owned rights; or

B. Assumes any liabilities with respect to the use of, or for damages resulting from the use of any information, apparatus, method, or process disclosed in this report.

As used in the above, "person acting on behalf of the Commission" includes any employee or contractor of the Commission, or employee of such contractor, to the extent that such employee or contractor of the Commission, or employee of such contractor prepares, disseminates, or provides access to, any information pursuant to his employment or contract with the Commission, or his employment with such a contractor. 


\section{CONTENTS}

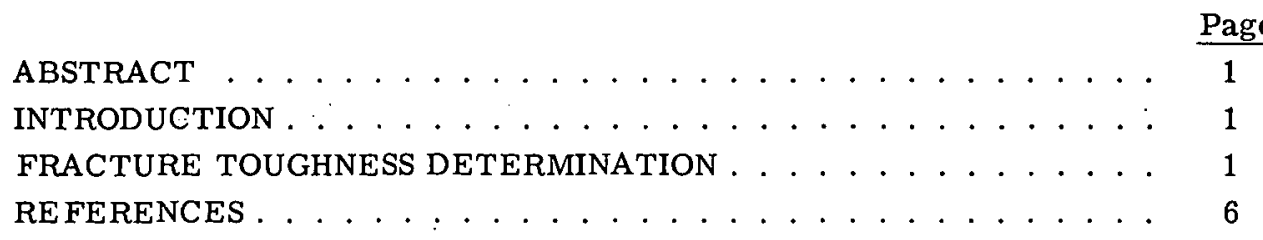




\title{
IMPACT TESTS AND FRACTURE TOUGHNESS
}

\author{
M. B. Reynolds
}

\begin{abstract}
The problems met in attempting to apply linear elastic fracture mechanics to moderately tough materials in thin sections are discussed. The possibility of using impact tests to estimate the toughness of such materials is suggested and the test conditions which must be met are listed.
\end{abstract}

\section{INTRODUCTION}

Over the years there have been developed a number of tests to classify, if not actually measure, the sensitivity of engineering alloys with respect to the presence of cracks, flaws, or other stress concentrators. Of these tests, the plane strain fracture toughness test is unquestionably the most sophisticated. The advent of linear elastic fracture mechanics and the success with which the technique has been used to predict the failure behavior of flawed brittle structures has led many to hope that the same or similar techniques could be used to predict the failure behavior of ductile structures. The virtue of linear elastic fracture mechanics has been that it made possible the prediction of the load. limit for a flawed structure in terms of flaw size and a single material parameter, the plane strain fracture toughness, $\mathrm{K}_{\mathrm{Ic}}$. The material property contribution to the fracture process can be specified completely hy a single constant only so long as there is negligible plastic deformation at the tip of the advancing crack. As the size of this plastic zone increases, particularly in relation to the size of the structure, it is necessary to correct the measured crack length by an amount dependent on the ratio of the toughness $\left(\mathrm{K}_{\mathrm{Ic}}\right)$ to the yield stress of the material. It should be noted that use of yield stress in the crack length correction term amounts to use of a second material property constant in the expression relating load limit to flaw size. The plane strain fracture toughness $\mathrm{K}_{\mathrm{Ic}}$ is proportional to the square root of $G_{I c}$, the fracture energy per unit area of fracture surface. $K_{I c}$ can then be a material constant and independent of structure size only if the energy expended in forming the layer of plastically deformed material accompanying the advancing crack is proportional to the crack area produced. For this condition to be met, the material thickness measured in a direction parallel to the crack edge must be great enough that maximum elastic constraint (and therefore minimum plastic zone size) is achieved over all but a negligible fraction of the length of the crack front. It is also necessary that the structure width be great enough relative to the crack depth that the inverse square root stress field characteristic of linear elastic.fracture mechanics is not greatly distorted by the proximity of a free surface. How great this width needs to be depends somewhat upon the toughness-yield stress ratio for the material; obviously the advancing plastic zone boundary must not intersect a free surface on the side of the structure opposite the crack front.

\section{FRACTURE TOUGHNESS DETERMINATION}

In a fracture toughness $\left(\mathrm{K}_{\mathrm{Ic}}\right)$ test, a specimen containing a crack prepared according to standardized procedures as specified by the Americal Society for Testing and Materials ${ }^{(1)}$ is loaded monotonically until unstable crack extension leading to failure occurs. Ideally, in a brittle material, the 
specimen should load linearly and elastically* up to the instability load. Because of the plastic deformation at the crack tip before crack extension, perfect linearity up to instability is not always achieved, and a $\mathrm{K}_{\mathrm{Ic}}$ test is not "valid" unless the deviation from linearity lies within specified limits. There are also specified limits to the ratio of specimen width to crack depth as well as to specimen thickness. This latter specification requires that for a "valid" $\mathrm{K}_{\mathrm{Ic}}$ determination the specimen thickness must be at least $2.5\left(\mathrm{~K}_{\mathrm{Ic}} / \sigma_{\mathrm{ys}}\right)^{2}$. It is an unfortunate fact that catastrophic failures have sometimes occurred in materials which are neither manufactured nor used in section thicknesses great enough to permit fabrication of a valid fracture toughness specimen based on the ASTM thickness criterion.

A "valid" $K_{I c}$ value is that number which defines a lower limit for the load which a flawed, thick-section structure can support. ${ }^{* *}$ It is quite possible that a flawed real structure, particularly in section thickness less than that required for a valid $\mathrm{K}_{\mathrm{Ic}}$ test, will fail at a load greater than that which would be predicted from the limiting $\mathrm{K}_{\mathrm{Ic}}$ value. In fact, a $\mathrm{K}_{\mathrm{c}}$ value from less than optimum test conditions may be more nearly descriptive of the actual failure load than is the true thick section $\mathrm{K}_{\mathrm{Ic}}$ value. For example it has been found possible to estimate failure loads in axially flawed low carbon steel pipes in terms of a constant having the dimensions of a stress intensity factor in spite of the fact that the section (wall) thickness was much less than that required for a valid fracture toughness test. *** Also, the values obtained in these pipe tests are not markedly different from those which would be obtained by extrapolation of valid $\mathrm{K}_{\mathrm{Ic}}$ versus temperature curves for similar material. ${ }^{(4)}$ These values should not be unexperted. The load limit for a brittle structure which can be treated by linear elastic fracture mechanics decreases monotonically with increasing flaw size and so does that for a structure made of material of sufficiently low yield strength that flaw extension occurs by ductile necking and tearing rather than by brittle fracture. The mathematical expression relating load limit to flaw size, in general, will not be so simple for the ductile case as for the brittle, but such expressions can be generated from experimental data in combination with some physical intuition. Furthermore, as the toughness of the material decreases, the relation of load limit and flaw size predicted by such an expression should approach that of linear elastic fracture mechanics. Deviation from the ideality of linear elastic fracture mechanics does not occur suddenly and discontinuously when a certain limiting combination of values of toughness, yield strength, and section thickness is reached. Rather there appears to be a "gray zone" in which constants having at least the dimensions of stress intensity factor can be measured under less than ideal test ccnditions and can be used to make approximate, if not completely accurate, estimates of limit loads for structures of section comparable to that of the test specimen.

Methods of Estimating Approximate Fracture Toughness

The ASTM restrictions on specimen size for valid $\mathrm{K}_{\mathrm{Ic}}$ tests were mentioned above. In some cases, a standard fracture toughness specimen (for example the 1X WOL specimen) will load linearly to a sharp instability although the $\mathrm{K}_{\mathrm{Ic}}$-to-yield strength ratio for the material is greater than the acceptable limit for the specimen section thickness. The critical stress intensity factor calculated from the instability load in this case should be indicative of the fracture behavior of the material in structures of this section thickness even though it does deviate from the true value of $\mathrm{K}_{\mathrm{Ic}}$.

* As indicated by crack opening or other suitable measure of deformation.

** Increasing refinement of $\mathrm{K}_{\mathrm{Ic}}$ measurement techniques should result in decreasing values until a limiting value is reached. This minimum value should represent the true $\mathrm{K}_{\mathrm{Ic}}$ for the material. *** Eiber, et al. , (2) obtained a value of approximately $300 \mathrm{ksi} \sqrt{\mathrm{in}}$. at about $600^{\circ} \mathrm{F}$; $\operatorname{Reynolds}(3)$ obtained a valuc of approximately $100 \mathrm{ksi}$ in. at $60^{\circ} \mathrm{F}$. Both investigators used ASTM A106B pipe. 
One source of approximate fracture toughness information which is of some value is the impact test. It was pointed out that $\mathrm{G}_{\mathrm{Ic}}$ is a measure of the energy required to create unit area of fracture surface. The impact fracture energy measured in a conventional Charpy test is the sum of the energy required to create the central flat fracture and the shear lips at the boundaries of the fracture surface. The energy required to form the shear lips normally is much greater than that to form the flat fracture. If the energy per unit area of flat fracture surface can be obtained either by extrapolation based on tests of specimens of different thickness ${ }^{(5)}$ or by suppressing the shear lips to negligible dimensions, this value W/A may be used to estimate an upper limit on $\mathrm{K}_{\mathrm{Ic}}{ }^{*}$ We may safely assume that

$$
G_{I c} \leq \frac{W}{A}
$$

and that

$$
\mathrm{K}_{\mathrm{Ic}} \leq \sqrt{\mathrm{E}(\mathrm{W} / \mathrm{A})}
$$

Shear lip suppression may be accomplished with varying degrees of success by nitriding, side notching, or fatigue pre-cracking the impact specimen used for fracture toughness estimation. Because of the increase in yield strength with increasing strain rate exhibited by most materials, dynamic fracture toughness values are lower than static $\mathrm{K}_{\mathrm{Ic}}$ values. This effect may to some extent compensate for the effect of plastic deformation (shear lip formation) at the specimen surfaces. To measure the rather low (a few foot-pounds) fracture energies obtained in such tests, a low range impact test machine is rcquired and corrections should be made for the kinetic energy of broken specimens. If all necessary corrections are made, the data obtained for materials of reasonably low toughness, such as low-strength ferritic steels, by the impact test are comparable with data obtained with standard fracture toughness specimens.

To illustrate this point, a comparison of the data from several specimen types is presented in Figure 1. All specimens with the exception of three of A106B were made from a single $1 \times 1$-inch bar of cold-rolled steel. Specimens used included:

\section{IMPACT}

$5.5 \times 1.0 \times 1.0 \mathrm{~cm}$, nitrided, $0.008 \mathrm{~cm}$ notch root;

$5.5 \times 1.0 \times 1.0 \mathrm{~cm}$, nitrided, $0.025 \mathrm{~cm}$ notch root;

$5.5 \times 1.0 \times 0.5 \mathrm{~cm}$, nitrided, $0.025 \mathrm{~cm}$ notch root;

$5.5 \times 1.27 \times 1.27 \mathrm{~cm}$, nitrided, $0.008 \mathrm{~cm}$ notch root and notched on 3 sides.

\section{STATIC}

$1 \times$ WOL, nitridẻd;

$1 \times 2 \times 5.5 \mathrm{~cm}, 3$ point-bend (pre-cracked Charpy).

The impact tests were made with a Manlabs Test machine of 24-ft-lb maximum capacity. Impact velocity was approximately $11.2 \mathrm{ft} / \mathrm{sec}$.

In loading the nitrided WOL specimens, initial pop-in which corresponded to the fracture of the nitride case was followed by crack arrest when the crack had extended into the tougher base material. Upon increasing the load, the specimens loaded linearly until a second pop-in followed by complete brittle fracture occurred. The load at the second pop-in was taken to be representative of the base material and was used in the calculation of $\mathrm{K}_{\mathrm{c}}$.

*Assuming the Poisson ratio $\nu$ to have the usual value of 0.3 , the factor $(1-2 \nu)$ in the expression relating $\mathrm{K}_{\mathrm{Ic}}$ to $\mathrm{G}_{\mathrm{Ic}}$ contributes but $5 \%$ to the value of $\mathrm{K}_{\mathrm{Ic}}$ and may be neglected here. 


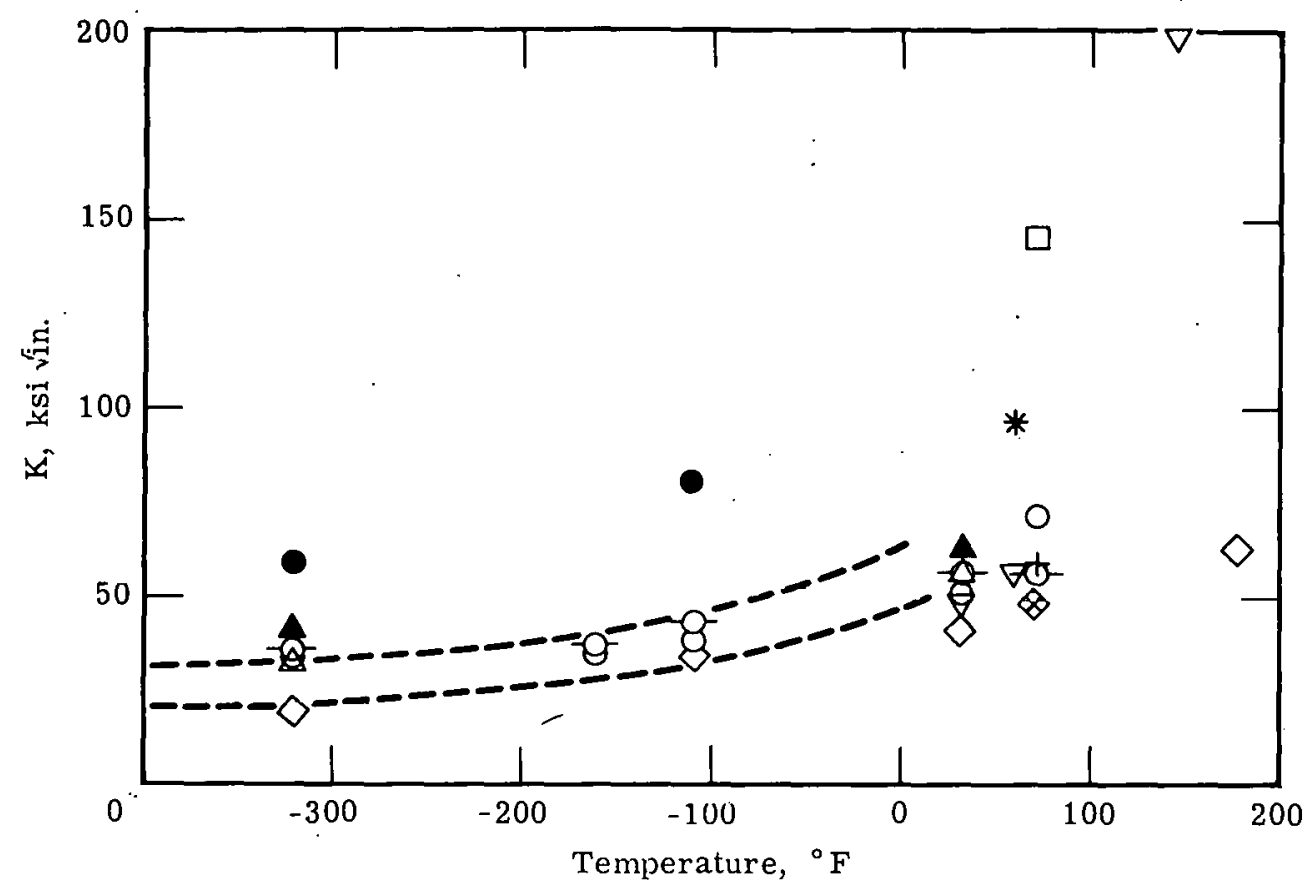

FIGURE 1. K VALUE: SPECIMEN DEPENDENCE
- $1 \times 1$ Charpy, Precracked
- $1 \times 1$ Charpy, Nitrided
O $1 \times \frac{1}{2}$ Charpy, Nitrided
$\triangle$ Side Notched, $0.008 \mathrm{~cm}$ root
- Side Notched, $0.025 \mathrm{~cm}$ root
$\nabla 1 \times 1$ Charpy, Nitrided A106
$\diamond 1 \mathrm{x}$ wOL, Nitrided

\author{
$\times 1 \mathrm{X}$ WOL, Fatigued \\ $+1 \times 2$ slow Bend \\ Dotted Lines Envelop Wessel \\ Data for Annealed A302B \\ $K_{C}$ Value from Burst Tests on Axially- \\ C flawed A106B Pipes \\ $\mathrm{K}_{\mathrm{c}}$ Value from Bend Test on Circum- \\ ferentially Flawed A106B Pipe
}

The dotted lines in Figure 1 envelop the valid $\mathrm{K}_{\mathrm{Ic}}$ data obtained by Wessel ${ }^{(4)}$ for $\mathrm{A} 3 \mathrm{C}_{0} \mathrm{~B}$ pressure vessel steel. Since this scatter band will also encompass available $\mathrm{K}_{\mathrm{Ic}}$ versus temperature dala for a surprising number of low-to-medium-strength ferritic steels at temperatures below the brittle-ductile transition, it is felt to be a reasonable standard against which to compare the impact test data. The fracture toughness of those materials which exhibit increasing yield strength with increasing strain rate decreases with increasing fracture velocity. Hence, the impact test $\mathrm{K}_{\mathrm{C}}$ values may be expected to lie below the $\mathrm{A} 302 \mathrm{~B}$ scatter band if the tests have been properly conducted; that they do not at low temperatures is probably because specimen residual kinetic energy, fraction, and other experimental errors become more significant at low energy values and lead to positive errors in the measured fracture energy. Negative errors, which would appear to exist if comparison with the $\mathrm{A} 302 \mathrm{~B}$ data is valid, would lead to conservative estimates of the load limits for real structures. It may he noted in passing that a scatter band encompassing the impact data in Figure 1 would be little wider than the A302B band.

There arc several ways of suppressing shear lip formation. All of them have some disadvantage which must be evaluated with reference to the material of interest. Fatigue cracking the notch in a Charpy specimen has little or no effect on shear lip formation along the sides of the specimen, but does produce some decrease in measured fracture energy because of the reduction in energy reequired to initiaté fracture. Surface nitriding is most effective in suppressing shear lip formation, 
but the process requires exposure of the specimen to elevated temperatures with possibility of resultant metallurgical changes. In the experiments upon which the data reported were based, subjecting standard Charpy specimens of low carbon steel to the same temperature cycle $\left(24\right.$ hours at $250^{\circ} \mathrm{F}$ ) as used in the nitriding process produced an increase in fracture energy as indicated by tests on standard Charpy specimens. It is quite possible that this temperature cycle would adversely alter the properties of some materials.

Although it does not yield W/A values so low as does the nitrided Charpy specimen, the $1.27 \mathrm{~cm}$ (1/2 inch) square, triple-notched specimen appears to be a good compromise when nitriding is precluded because of adverse thermal effects. The three notches of $0.008 \mathrm{~cm}$ or smaller root radius are easily cut by broaching and can be further sharpened if desired by pressing a hardened knife edge into the notch root. This specimen is of larger-than-standard Charpy cross section and may . require some modification of the test machine to accommodate it, but side-notching a standard Charpy specimen considerably reduces the fracture area and increases the ratio of shear lip to flat fracture area. Early, rather qualitative tests with this specinen appeared encouraging, but to date no further effort has been made to optimize its dimension.

In summary, it would appear that the impact test may be a useful source of upper-limit. fracture toughness values where available section thickness does not permit valid fracture toughness testing under the ASTM criteria. For impact W/A data to be applicable to $\mathrm{K}_{\mathrm{c}}$ estimation the following conditions must be met:

1. A sensitive, rigid impact test machine must be used to minimize energy absorption by vibration and machine friction.

2. All possible corrections must be made for broken specimen kinetic energy, windage, and so forth, particularly at low energy values.

3 . The contribution of shear lip formation to the measured impact fracture energy must be removed either by an extrapolation process based on multiple specimen widths or by modification of the specimen by nitriding, side notching, or other means eithcr to eliminate shear lip formation or to reduce it to an insignificant portion of the fracture surface.

Impact fracture testing is not recommended as a replacement for valid static fracture toughness testing, but rather for those cases in which nothing else is available for estimating fracture toughness. 


\section{REFERENCES}

1. ASTM, E-24 Sub I Task Grüp "Recomnended Praclice fór Plane Strain Fracture Toughness Testing."

W. F. Brown, Jr., and J. E. Srawley, "Plane Strain Crack Toughness Testing of High Strength Metallic Materials," ASTM, Spec. Tech. Pub. No. 410 (1967).

2. R. J. Eibcr, A. M, Hein, A. R. Duffy, and T. S. Atterbury, "Investigation of the Initiation and Extent of Ductile Pipe Rupture, "Battelle Memorial Institute, Columbus, Ohio, January 1967 (BMI-1793).

3. M. B. Reynolds, "Failure Behavior in ASTM A106B Pipes Containing Axial Through-Wall Flaws," Nucleonics Laboratory, General Electric Company, Pleasanton, Calif., (GEAP-5620).

4. E. T. Wessel, "State of the Art of the WOL Specimen for K $\mathrm{K}_{\mathrm{Ic}}$ Fracture Toughness Testing," Eng. Fract. Mech. 1, 77, (1968).

5. J. I. Bluhm, "A Model for the Effect of Thickness on Fracture Toughness," Proc. ASTM 61, 1324, (1961).

"Geometry Effect on Shear Lip and Fracture Toughness Transition Temperature for Bimodel Fracture," Proc. ASTM, 62, 1, (1962). 
Aerojet General

Idaho Falls, Idaho 83401

Attn: W. E. Nyer

Advisory Committee on Reactor

Dr. Spencer H. Bush

Consultant to the Director

Battelle Memorial Institute

Pacific Northwest Laboratory

Richland, Washington

Advisory Committee on Reactor Safeguards

Mr. Haruld Elherington

84 Lighthouse Drive

Jupiter, Florida 33458

Advisory Committee on Reactor Safeguards

Dr. William L. Faith

2540 Huntington Drive

San Marino, California 91108

Advisory Committee on Reactor Safeguards

Dr. Franklin A. Gifford, Jr., Director

Atmospheric Turbulence and Diffusion Laboratory, ESSA

c/o U. S. Atomic Energy Commission

P. O. Box E

Oak Ridge, Tennessee 37830

Advisory Committee on Reactor Safeguards

Dr. Stephen H. Hanauer

Professor of Nuclear Engineering

606 Dougherty Hall

University of Tennessee

Knoxville, Tennessee 37916

Advisory Committee on Reactor Safeguards

$\mathrm{Dr}$. Joseph M. Hendrie

Nuclear Engineering Department

Brookhaven National Laboratory

Upton, New York 11973

Advisory Committee on Reactor Safeguards

Dr. Herbert S. Isbin

Department of Chemical Engineering

University of Minnesota

Minneapolis, Minnesota 55455

Advisory Committee on Reactor Safeguards Mr. Harold G. Mangelsdorf

78 Knollwood Road

Short Hills, New Jersey 07078.

Advisory Committee on Reactor Safeguards

Dr. Harry O. Monson, Senior Engineer

I.aboratory Director's Office

Argonne National Laboratory

9700 South Cass Avenue

Argonne, Illinois 60439 
Advisory Committee on Reactor Safeguards

Dr. Arlie A. O'Kelly

2421 West Rowland Avenue

Littleton, Colorado 80120

Advisory Committee on Reactor Safeguards

Dr. David Okrent, Senior Physicist

Laboratory Director's Office

Argonne National Laboratory

9700 South Cass Avenue

Argonne, Illinois 60439

Advisory Committee on Reactor Safeguards

Dean Nunzio J. Palladino

College of Engineering

The Pennsylvania State University

101 Hammond Building

University Park, Pennsylvania 16802

Advisory Committee on Reactor Safeguards

Dr. William R. Stratton

Los Alamos Scientific Laboratory

P. O. Box 1663

Los Alamos, New Mexico 87544

Advisory Committee on Reactor Safeguards

Dr. Carroll W. Zabel

Director of Research

University of Houston

Cullen Boulevard

Houston, Texas 77004

Mr. Raymond F. Fraley

Executive Secretary

Advisory Committee on Reactor Safeguards

U. S. Atomic Energy Commission

Room 1034-H

Washington, D. C. 20545

Argonne National Laboratory

9700 South Cass Avenue

Argonne, Illinois

Attn: Dr. P. Lottes

Atț: Dr. C. E. Dickerman

Attn: Dr. R. O. Ivins

Attn: Dr. S. Fistedis

Attn: Dr. R. C. Vogel

Attn: LMFBR Program Office

Attn: Mr. A. Amorosi

Attn: Dr. L. Baker

Atomic Energy Commission

Division of Reactor Development and Technology

Washington, D. C. 20545

Attn: Col. R. L. Ednie

Asst. Director for Army Reactors

1

1

Attn: Mr. M. A. Rosen

Asst. Driector for Plant Engrg.

Attn: Mr. M. J. Whitman

Asst. Director for Program Analysis

Attn: Dr. E. E. Sinclair

Asst. Director for Reactor Technology

Attn: Mr. A. Giambusso

Asst. Director for Project Management

Attn: Mr. E. E. Kintner

Asst. Director for Reactor Engineering

Attn: Mr. .T. W. Crawford

Asst. Director for Engineering Standards

1

1

1

1

1

1

1 
Atomic Energy Commission

Division of Compliance, Region IV

10395 West Colfas Avenue

Denver, Colorado 80215

Attn: Dr. Donald Walker

Atomic Energy Commission

Division of Compliance

Washington, D. C. 20545

Attn: Mr. L. Kornblith, Jr.

Atomic Energy Commission

Division of Operational Safety

Washington, D. C. 20545

Attn: Mr, H. Gilbert

Atomic Energy Commission

Division of Reactor Standards

Washington, D. C. 20545

Attn: Mr. E. G. Case

$\Lambda$ ttn: Mr. M. Bolotsky

Attn: Mr. A. B. Holt

Attn: Mr. R. Waterfield

Attn: Dr. G. Burley

Attn: Mr. J. J. NiNunno

Atomic Energy Commission

Water Projects Branch

Division of Reactor Development and Technology

Washington, D. C. 20545

Attn: Mr. D. E. Erb

Atomic Energy Commission

Naval Reactors Branch

Division of Reactor Development and Technology

Washington, D. C.20545

Attn: Mr. R. S. Brodsky

Atomic Energy Commission

Division of Reactor Development and Technology

Washington, D. C. 20545

Attn: Dr. J. A. Lieberman

Alomic Energy Commission

Division of Reactor Development and 'T'echnology

Washington, D. C. 20545

Attn: Mr. S. A. Szawlewicz

Atomic Energy Commission

Division of Production

Washington, D. C. 20545

Attn: Mr. George B. Pleat

Atomic Energy Commission

- $\%$ Gulf General Atomic, Inc.

P. O. Box 608

San Diego, California 92112

Attn: Mr. Russell H. Ball

Atomics International

P. Bü 309

Canoga Park, California

Attn:. Dr. H. Morewitz

Atomlc Energy Commission

Maritime Reactors Branch

Division of Reactor Development

Washington, D. C. 20545 
Babcock and Wi lcox Company

Washington Operarions Office

1725 I Street, N. W.

Washington, D. C. 20006

Attn: Mr. L. R. Weissert

Babcock and Wilcox Company

P. O. Box 1260

Lynchburg, Virginia

Attn: Mr. Robert Wascher

Battelle Memorial Institute

505 King Avenue

Columbus, Ohio 43201

Attn: Dr. D. N. Sunderman

Attn: Dr. D. I. Morrison

Attn: Mr. S. Paprocki

Attn: Mr. A. R. Duffy,

Brookhaven National Laboratory

Upton, Long Island, New York 11973

Attn: A. W. Castleman

University of California

Office of Research Services

Berkeley, California 94720

Attn: Prof. V. E. Schrock

Cảnoga Park Area Office

P. O. Box 591

Canoga Park, California 91305

Attn: Mr. R. L. Morgan

RDT Senior Site Rep.

Combustion Engineering, Inc.

Nuclear Division

P. O. Box 500

Windsur, Connecticut 06095

Attn: Mr. M. F. Valerino

Chicago Operations Office

Atomic Energy Commission

9800 South Ca.ss Avenue

Argonne, Illinois 60439

Attn: Mr. D. M. Gardiner

Gulf General Atomic, Inc.

P. Box 608

San Diego, California 92112

Attn: Mr. A. J. Goodjohn

Harvard Air Cleảning Laboratory

Harvard University

665 Huntington Avenue

Boston, Massachusetts 02190

IIT Research Institute

10 W. 35th Street

Chicago, Illinois 60616

Attn: Dr. T. A. Zaker

IIT Research Institute

$10 \mathrm{~W}$. 35th Street

Chicago, Illinois 60616

Attn: Mr. F. V. Gallagher

Idaho Operations Office

Atomic Energy Commission

P. O. BnX 2108

Idaho Falls, Idaho 83401

Attn: Mr. D. Williams 
Liquid Metal Engineering Center

P. O. Box 309

Canoga Park, California 91304

Attn: R. W. Dickinson

Los Alamos Scientific Laboratory

P. O. Box 1663

Los Alamos, New Mexico 87544

.Attn: Mr. J. H. Russel, K Division

MPR Associates, Inc.

1140 Connecticut Avenue, N. W.

Washington, D. C. 20036

Attn: Mr. T. Rockwell III, Chairman AIR Safety Task Force

National Bureau of Standards

Washington, D. C. 20545

Attn: Dr. C. Muehlhause

Naval Urdnance Laboratory

White Oak

Silver Spring, Maryland

Attn: Mr. James Proctor

North Carolina State University

Department of Mechanical Engineering

Raleigh, North Carolina 27607

Attn: Prof. M. N. Ozisik

Nuclear Fuels Services

West Valley, New York 14171

Attn: Mr. Russel P. Wischow

Oak Ridge Operations Office

Atomic Energy Commission

Oak Radge, Tennessee 37830

Attn: Mr. W. L. Smalley

Oak Ridge National Laboratory

P. O. Box Y

Oak Ridge, Tennessee 37830

Nuclear Safety Information Center

$\Lambda$ ttn: Mr. Jocl Buchanan

HTGR Program Coordination

Attn: Mr. D. B. Trauger

2

Attn: HTGR Safety Program Office

Attn: Mr. W. B. Cottrell

Chemical Technology Division

Oak Ridge National Laboratory

P. O. Box Y

Oalk Ridgc, Tennessce 37830

Attn: Mr. D. Ferguson

Attn: Mr. R. Blanco

Technical Information Division

P. O. Box X

Oak Ridge, Tennessee 37830

Attn: W. F. Ferguson

Pacific Northwest Laboratories

P. O. Box 999

Richland, Washington 99352

Attn: Mr. J. C. Spanner

Attn: Mr. G. Rogers

Attn: Dr. J. Batch

Attn: Mr. R. Nightingale

Attn: Mr. $\mathrm{I}_{\text {, }}$. Schwendiman 
Phillips Petroleum Company

P. O. Box 1259

Idaho Falls, Idaho 83401

Attn: Mr. Curt Haire

Attn: Dr. S. Forbes

Attn: Mr. T. R. Wilson

Attn: Mr. N. K. Sowards

Attn: Water Reactor Safety Program Office

Attn: Manager, WRSPO

Richland Operations Office

P. O. Box 500

Richland, Washington 99352

Attn: Mr. C. Robinson

Attn: Mr. A. S. Waterhouse

Attn: Mr. A. Brunstad

San Francisco Operations Office

Atomic Energy Commission

2111 Bancroft Way

Berkeley, California 94704

Attn: Mr. C. V. Backlund

Savannah River Laboratories

E. I. duPont deNemours and Company

Aiken, South Carolina 29802

Attn: Mr. A. H. Peters

TRW Inc.

TRW Systems Group

One Space Park

Redondo Beach, California 90278

Attn: Dr. D. B. Langmuir

Attn: Mr. S. M. Zivi

Westinghouse Electric Corporation

Atomic Power Division

P. O. Box 355

Pittsburgh, Pennsylvania 15230

Attn: Mr. R. A. Wiesemann

Attn: Dr. D. Fletcher

Attn: Dr. E. Beckjord

Attn: Dr. F. M. Heck

Attn: Dr. H. Graves

Westinghouse Electric Corporation

Hcat Transfer Division

Lester Branch Box 8175

Philadelphia, Pennsylvania 19113

Attn: Mr. A. Lohmeier

Southern Nuclear Engineering, Inc.

P. O. Box. 10

Dunedin, . Florida 33528

Attn: Mr. Gilbert Brown

Pacific Northwest Laboratories

P. O. Box 999

Richland, Washington 99352

Attn: E. R. Astley, Manager FFTF Project

Atomic Energy Commission

Division of Reactor Standards

Washington, D. C. 20545

Attn: Mr. R. Impara

Oak Ridge National Laboratory

Attn: Mr. P. Rittenhouse 
United Nuclear Corporation

Development Division

Grasslands Road

Elmsford, New York 10523

Attn: Dr. C. Graves

Mr. Edward T. Wessel

Research and Development Center

Westinghousc Elcctric Corporation

Beulah Road, Churchill Boro

Pittsburgh, Pennsylvania 15235

William E. Cooper

Lesselle and Associates

303 Bear Hill Road

Waltham, Massachusetts

Roger W. Staehle

Metallurgy Department

Ohio Stale University

Columbus, Ohio

Mr. Ralph Jones

Division of Reactor Development

U. S. Atomic Energy Commission

Washington 25, D. C.

Mr. H. K. Marks

Room 2N83

Department of the Navy

Washington, D. C.

H. Thielsch

140 Shaw Avenue

Cranston 5, Rhode Island

Mr. F. M. Moschine

Westinghouse Electric Cunuany

Atomic Power Department

P. O. Box 355

Pittsburgh, Pennsylvania 15230

Robert Cloud

Bettis Atomic Power Laboratory

P. O. Box 79

West Mifflin, Pennsylvania 15122

Professor C. E. Taylor

Department of Theoretical and Applied Mechanics

University of Illinois

Urbana, Illinois

Mr. E. Beauchamp-Nobbs

Annapolis, Maryland

U. S. Atomic Energy Commission

Division of Technical Information Extension

P. O. Box 62

Oak Ridge, Tennessee

U. S. Atomic Energy Commission

Division of Reactor Licensing

Washington, D. C. 20545

Attn: S. S. Pawlicki

USAEC Site Representative

General Electric Company

Sunnyvale, California 94086

Att.n: Joel Levy, Senior Site Rep. 
Mr. B. L. Greenstreet

P. O. Box Y

Oak Ridge National Laboratory

Oak Ridge, Tennessee

F. J. Witt

P. O. BoX Y

1

ORNL - Oak Ridge, Tennessee

Commonwealth Edison Company

2

Dresden Nuclear Power Station

Rural Route 1

Morris, Illinois 60450

Attn: H. K. Hoyt

Commonwealth Edison Company

System Mechanical and Structural Engineer

72 West Adams Street

Chicago, Illinois 60690

4

Attn: N. A. Ker shaw

United Kingdom Atomic Energy Authority

Reactor Materials Laboratory

Wigshaw Lane, Culcheth

Warrington, Lancs.

England

Attn: R. W. Nichols

Atomic Energy of Canada Limited

Chalk River Nuclear Laboratories

Chalk River, Ontario, Canada 